\title{
WHAT HAS BEEN (SHORT) WRITTEN ABOUT GREENWASHING: A BIBLIOMETRIC RESEARCH AND A CRITICAL ANALYSIS OF THE ARTICLES FOUND REGARDING THIS THEME
}

\author{
Tais Pasquotto Andreoli \\ Doutoranda em Administração \\ Universidade Municipal de São Caetano do Sul (USCS) \\ São Caetano do Sul - São Paulo - Brasil \\ tais_pa@hotmail.com
}

\author{
Aline Crespo \\ Doutoranda em Administração \\ Universidade Municipal de São Caetano do Sul (USCS) \\ São Caetano do Sul - São Paulo - Brasil \\ alinecrespo@ hotmail.com \\ Silvio Minciotti \\ Doutor em Administração \\ Universidade Municipal de São Caetano do Sul (USCS) \\ São Caetano do Sul - São Paulo - Brasil \\ silviominciotti@uol.com.br
}

\begin{abstract}
The work's purpose was mapping and analyzing the academic production concerning the greenwashing subject. Thus, a theoretical framework on green marketing and greenwashing has been developed. The method adopted was a bibliometric research and a critical analysis associated with critical analysis of the content of the articles found, targeting the academic publications on the greenwashing term and other correlates, in the main Business Administration events in Brasil (Semead, EnAnpad and EMA) and on the most acknowledged scientific databases worldwide (Proquest, Web of Science, Capes, Scopus, Scielo and Spell). Therefore, it has been possible to realize that the greenwashing subject, despite responding for a recent and relevant production, is still not very studied by the academy, especially in depth. In this sense, of the 42 articles identified, it was analyzed that only 17 actually work with the theme, and the others only mention it or work as superficially or as a backdrop. It was observed that the analysis focus of these 17 articles focused on the investigation and empirical identification of greenwashing or on possible aspects that influence or are influenced by this practice, such as market evaluation, role of the media and government and the impact on the consumer behavior. Considering this, new studies are concerning the subject, mainly from the perspective of how is it possible to undermine or combat this practice concerning the organizations, highlighting, also, the potentiality of negative impacts resulting from it both in society as a whole and in the organizational and consumer markets.
\end{abstract}

Keywords: Environmental concern. Green marketing. Greenwashing. Academic production. Bibliographic survey.

\section{O QUE FOI (POUCO) ESCRITO SOBRE GREENWASHING: UMA PESQUISA BIBLIOMÉTRICA E UMA ANÁLISE CRÍTICA DOS ARTIGOS ENCONTRADOS SOBRE ESTE TEMA}

\section{RESUMO}

O objetivo do trabalho foi mapear e analisar a produção acadêmica em relação ao assunto greenwashing. Assim, foi desenvolvido um quadro teórico sobre marketing verde e greenwashing. O método adotado foi uma pesquisa bibliométrica e uma análise crítica associada à análise crítica do conteúdo dos artigos encontrados, visando as publicações acadêmicas no termo greenwashing e outros correlatos, nos principais eventos da Administração de Empresas no Brasil (Semead, EnAnpad e EMA) E nas bases de dados científicas mais reconhecidas em todo o mundo (Proquest, Web of Science, Capes, Scopus, Scielo e Spell). Portanto, foi possível perceber que o assunto greenwashing, apesar de responder por uma produção recente e relevante, ainda não é muito estudado pela academia, especialmente em profundidade. Nesse sentido, dos 42 artigos identificados, foi analisado que apenas 17 realmente trabalham com o tema, e os outros apenas o mencionam ou trabalham de forma superficial ou como pano de fundo. Observou-se que o foco de análise desses 17 artigos se concentrou na investigação e identificação empírica de greenwashing ou em possíveis aspectos que influenciam ou são influenciados por esta prática, como avaliação de mercado, papel da mídia e do governo e impacto no consumidor comportamento. Considerando isso, novos estudos abordam o assunto, principalmente a partir da perspectiva de como é possível minar ou combater esta prática em relação às organizações, destacando também a potencialidade dos impactos negativos resultantes tanto na sociedade como um todo quanto no âmbito organizacional e no mercado consumidor.

Palavras-chave: Preocupação ambiental; Marketing verde; Lavagem ecológica; Produção acadêmica; Pesquisa bibliográfica. 


\section{INTRODUCTION}

The discussion development on environmental and climate changes in international congresses has triggered the debates on the subject in society, which ended up influencing a change in consumers' behavior. As a consequence, the organizations have been forced to adopt environmental sustainability practices, as the consumers started to value products which manufacturing process had been included in an environmental preservation context.

Seen as a branch of societal marketing, which main focus is a market practice based on actions that include sustainability and society's welfare, the green marketing main purpose is a market practice based on actions including environmental concern, by means of valuing actions aimed at the environment preservation (Motta \& Oliveira, 2007; Lopes \& Pacagnan, 2014).

According to Polonski (1994), the green marketing has been used, at first, in good or service trading actions which intended to cause the least possible impact to the environment. Thus, the green marketing is responsible for managing the exchange relations among individuals so that they feel satisfied, however, without damaging the environment (Motta \& Oliveira, 2007).

As green marketing strategies are used, the companies achieve benefits, by means of the community, their provider and their customer positive assessment (Rodrigues et al., 2013). However, in order to keep up with such environmental concern trend and benefit from it, some organizations end up using green mottos unrealistically (Budisnky \& Bryant, 2013). This inconsistent 'green speech' worded out by the organization, without a practical backup is conceived as greenwashing (Antunes, Santos \& Hurtado, 2015).

Due to the abovementioned, the work purpose is mapping the academic production concerning the greenwashing subject. Thus, a theoretical framework has been developed on green marketing and greenwashing. The method used was a bibliometric research and a critical analysis, targeting the academic publications on the greenwashing term and other correlates, in the main Business Administration events in the country (Semead, EnAnpad and EMA) and in the most widely acknowledged scientific databases (Proquest, Web of Science, Capes, Scopus, Scielo and Spell).

\section{GREEN MARKETING AND GREENWASHING}

The issues related to environmental and climate changes highlight a series of discussions based not only on international congresses, but also discussed in society, which shows to be increasingly concerned with this kind of issues. This concern also permeates the organizational scope, as the consumers have acquired other consumption habits, which resulted in the product choice pattern change. Thus, the consumer became more critical concerning not only the product choice, but also the actions performed by the organizations that use as strategy the environment preservation motto strategy, as they broadcast, for instance, advertisements that relate positive ecological connotations to their products (Guimarães, 2012).

From this consumer behavior change, a competition environment has been set forth among the companies, which started to aim marketing strategies in order to develop a new value proposition, based on socio-environmental responsibility. Thus, the green marketing concept arises. According to Polonski (1994), the first practices aimed at green marketing application have been used in good or service trading actions which purpose was not only meeting consumer needs, but also causing the least possible impact to the environment.

Even if the green marketing term is the most widely used, it is worth noting that other authors explore such theme using other definitions, such as ecological marketing (Motta \& Oliveira, 2007; Motta, 2008), environmental marketing (Conejero \& Neves, 2006) or even ecomarketing (Abdala, Guzzo \& Santos, 2010).

For some authors (Motta \& Oliveira, 2007; Lopes \& Pacagnan, 2014), green marketing can be seen as a societal marketing branch, which considers the actions aimed at the problems related to life in society, social responsibility and population welfare, including ecological and environmental issues. On its turn, the green marketing, as a more direct societal marketing application form, is related to a marketing philosophy based on environmental concern, which composite includes, besides the traditional marketing composite, the respect to society as a whole by means of environment preservation actions (Motta, 2008).

Green marketing is, therefore, including criteria such as socio-environmental responsibility and sustainable development related to marketing (Motta \& Oliveira, 2007; Lopes \& Pacagnan, 2014). In other words, green marketing can be seen as a strategy set which aims at promoting products that use the 
environmental responsibility, whether related to its features or its systems and business policy (Prakash, 2002). Thus, one can state that the green marketing main purpose is managing exchange relations among individuals, so that they meet not only consumers', but also environment's requirements (Motta \& Oliveira, 2007).

Rodrigues et al. (2013) present some benefits that organizations can achieve by means of using green marketing strategies. At first the relationship with the community, suppliers and customers improves, from the time the company starts to be acknowledged by the environmentally sustainable practices. Secondly, such practices enable a better resource use and a consequent waste elimination. Moreover, the organizations can also take advantage of a better financial market assessment, incurring from good environmental practices fostered by such market by means of credit offer aimed at projects that stand up for ecological causes. More firmly, Ottman (1994) states that the organizations take chances when they do not respond to environmental issues and highlights that the consumers become partners of brands that adopt ecologically correct principles.

Terres and Branchi (2013), based on author conceptions such as Polonsky (1994), Bansal (2000), and Gisberg and Bloom (2004), report that the companies are motivated to use and execute green marketing practices to assist sustainable action development. Such actions are triggered by the outside environment, and they are often related only to fulfilling legal requirements, in order not to be punished either by the government or by regulatory agencies. Another triggering factor to adopt the green marketing practice is the competition, as by adopting such practices the company becomes capable of developing competitive features in relation to its competitors.

Green marketing is present in organization strategy development, whether by the pressure performed by society, or with the intent of fostering a brand image which cares for the environment. Another organizational actions related to green marketing concern ethical and relevant issues linked to environment, such as care in the manufacturing process, packaging development and distribution logistics, and aim specifically at supporting reaching the organization goals (Prado et al, 2011).

However, in order to keep up with the environmental concern trend and take advantage of green marketing benefits, specially of the green image before the consumers, some organizations end up adopting green mottos unrealistically (Budisnky \& Bryant, 2013). Such liar speech or posture concerning organization green practices, without practical backup, is conceived as greenwashing (Antunes, Santos \& Hurtado, 2015).

Greenwashing is a term created in 1990, which refers to the whitewash expression, which means a process of concealing one's errors and deceptions, causing one's reputation to remain clean (Abdala, Guzzo $\&$ Santos, 2010). Therefore, greenwashing denotes a green washing of the products or the organization itself, so that, thus, they seem ecologically correct, even though not necessarily being so.

The greenwashing issue becomes stronger with the evidence that many environmental actions publicized by the organizations, increasingly broadcast by the media, are not backed up or actually proven (Jahdi \& Acikdilli, 2009). Such questioning takes place concerning the organization speech (Walker \& Wan, 2012; Turano, Cherman \& Franca, 2014), and the sustainability reports and socio-environmental responsibility policies (Lins \& Silva, 2009; Parguel, Benoit-Moreau \& Larceneux, 2011; Hahn \& Lülfs, 2013).

In other words, the greenwashing action stands out when the organization uses any feature or highlights some benefit related to the environment and/or to the environmental problematic, but fails to prove their veracity (NYILASY; GANGADHARBATLA; PALADINO, 2013). Thus, greenwashing can be seen as a publicity stunt, misinformation, an intentional action to mislead or deceive consumer with false claims on organization environmental posture, disguising or masking the product or organizational image (PARGUEL; BENÔIT-MOREAU; LARCENEUX, 2011).

\section{METHOD}

In order to achieve the goals proposed herein, a bibliometric research was used, performing a data survey related to the production, quality and quantity of academic publications that include the greenwashing subject. That allowed a general mapping of what has been produced on the subject, not only to consolidate what has been studied so far, but also to enable a critical analyses of what has been developed.

Even though one knows the greenwashing term correct spelling, similar terms have been searched based on the previous knowledge of its occurrence. Thus, from April to May, 2016, the terms 'greenwashing', 'green washing', 'greenwash', 'green wash', 'lavagem verde' (greenwashing), 'maquiagem verde' (green 
makeup), 'propaganda falsa verde' (false green advertising) and 'propaganda enganosa verde' (deceiving green advertising) were searched.

The search locations were: all issue annals of the events of Semead - Business Administration Seminars, held by the Economy and Business Administration College of Universidade de São Paulo (FEA/USP), EnAnpad - Anpad Meeting - and EMA - Marketing Meeting - both held by Anpad - Business Administration National Post-Graduation and Research Association, and also the Proquest, Web of Science, Capes journal portal, Scopus, Scielo and Spell platforms.

The results have been filtered in articles published in journals rated by Qualis 2014 in the Business Administration, Accounting and Tourism (ACT) field. Thus, the other results found, such as reports, articles submitted in conferences, articles published in journals not rated in Qualis, dissertations and theses, were disregarded. It is worth noting that all search options provided by each platform abovementioned were performed.

\section{RESULT ANALYSIS}

The result analysis is divided in two subtopics. Firstly, there is the article survey, in which the search procedure and article selection to be included in the analysis scope is described in details. Afterwards, there is the selected article analysis, showing the criteria set forth and arguing on results found from them.

\subsection{Article survey}

In the Semead - Business Administration Seminars (FEA/USP) events, in the yearly editions from 1998 to 2015, and also in the EnAnpad events, yearly editions from 1997 to 2015, and EMA (Anpad) events, biannual editions from 2004 to 2016, no articles were found with any of the terms searched.

In the Proquest platform, 125 results were achieved with the terms searched, among which 25 articles were published in journals rated by Qualis, and eight in Business Administration, Account and Tourism (ACT) field. By repeating the search by means of advanced search device, besides the articles abovementioned, another article published in a journal rated in ACT field was found, adding 9 articles selected in this platform. In the Web of Science platform, searching in title and by topic, 245 results were achieved, out of which 82 are articles published in journals rated by Qualis, and 38 in ACT field.

In Capes Journal Portal, 323 results were achieved, identifying 77 articles published in journals rated by Qualis, and 36 in ACT field. In Scopus Portal, the search was performed by article title, abstract and keywords, locating 175 results, and 24 articles are published in journals rated in ACT field. In the Scielo platform searching for the title, subject and abstract words, only one article was found, published in journal rated by Qualis in ACT field. In the Spell platform, searching in keywords, title and abstract, three articles published in journals rated by Qualis in ACT field were found. The results by search term and platform used are detailed in Table 1.

\begin{tabular}{|c|c|c|c|c|c|c|c|c|}
\hline \multirow{2}{*}{$\begin{array}{c}\text { Platfo } \\
\text { rm }\end{array}$} & \multicolumn{6}{|c|}{ Term search general result } & \multirow{2}{*}{$\begin{array}{c}\text { General } \\
\text { Qualis }\end{array}$} & \multirow{2}{*}{$\begin{array}{l}\text { ACT } \\
\text { Qualis }\end{array}$} \\
\hline & Greenwashing & $\begin{array}{c}\text { Green } \\
\text { washing }\end{array}$ & Greenwash & $\begin{array}{c}\text { Green } \\
\text { wash }\end{array}$ & $\begin{array}{l}\text { Propaganda } \\
\text { falsa verde } \\
\text { (False green } \\
\text { advertising) }\end{array}$ & $\begin{array}{c}\text { Maquiagem } \\
\text { verde } \\
\text { (Green } \\
\text { makeup) }\end{array}$ & & \\
\hline $\begin{array}{c}\text { Proqu } \\
\text { est }\end{array}$ & 59 & 15 & 46 & 6 & 0 & 0 & 42 & 9 \\
\hline $\begin{array}{l}\text { WSci } \\
\text { ence }\end{array}$ & 124 & 50 & 58 & 13 & 0 & 0 & 95 & 38 \\
\hline Capes & 180 & 36 & 94 & 11 & 1 & 1 & 78 & 36 \\
\hline $\begin{array}{c}\text { Scopu } \\
\text { s }\end{array}$ & 145 & 5 & 5 & 20 & 0 & 0 & 25 & 24 \\
\hline Scielo & 1 & 0 & 0 & 0 & 0 & 0 & 1 & 1 \\
\hline Spell & 0 & 0 & 3 & 0 & 0 & 0 & 3 & 3 \\
\hline Total & 509 & 106 & 206 & 50 & 1 & 1 & 244 & 111 \\
\hline
\end{tabular}

Source: Developed by the authors. 
To sum up, out of 873 results found, 244 articles in total published in journals rated by Qualis were identified, and 111 articles were found in ACT field (Table 1). The other results found, such as reports, articles presented in conferences, articles published in journals not rated in Qualis, dissertations and theses, among others, were disregarded.

What is more, out of this total 111 articles published in journals rated by Qualis in ACT field, due to 65 duplicity cases identified, which were eliminated later, 46 articles resulted. More than that, out of such 46 remaining ones, one article was eliminated as it included only the abstract (Mandarin language) and other three ones, as they were unrelated subjects (such as green detergent or green washing process), resulting, indeed, in 42 articles selected for analysis.

\subsection{Selected article analysis}

Concerning the 42 analyzed article publication date, it has been noted that the oldest publication dates from 1995. However, it is an article that only mentions the greenwashing occurrence possibility, as an attempt to promote the organizations, not actually developing the subject. The next result found took place in 2003, and it is an article that really develops the subject. The other articles are concentrated from 2007 to 2015, and 2014 presented the greatest publication number, with 11 articles. The results found evidence the greenwashing timeliness, which production progresses indeed from 2007 on.

Figura 1: Publication Evolution

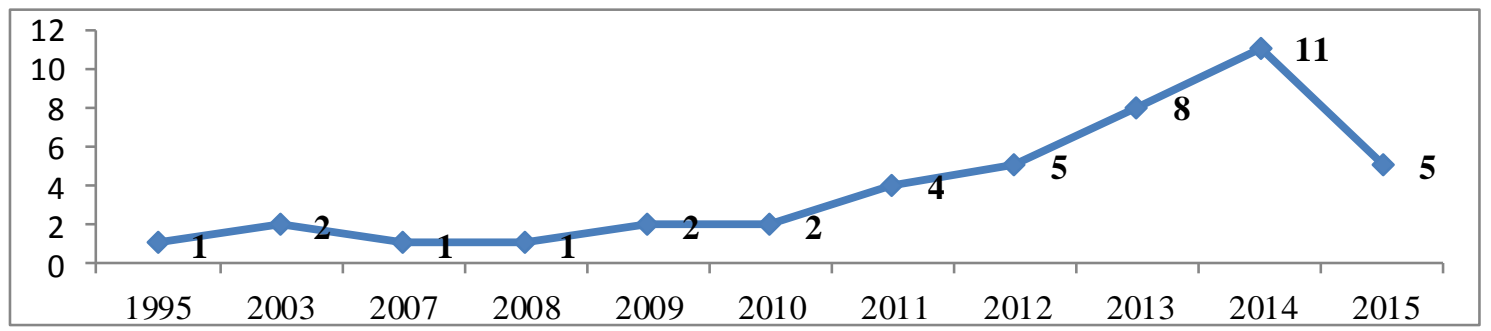

Source: Developed by the authors.

Moreover, the subject relevance can be seen when one realizes the largest portion of articles (26) was published in journals which rating, according to 2014 Qualis list, is A1. Five articles were published in journals rated as A2, besides eight ones published in journals rated as B1. Another three publications are divided in journals with $\mathrm{B} 2, \mathrm{~B} 3$ and $\mathrm{B} 4$ rating.

Only four articles were published in Brazilian journals, the other ones were published in international journals, out of which the European Journal Business Ethics stood out, with eleven publications. 110 different authors were accounted for, among which only four are repeated, with two articles each (Iraldo, Lyon, Relano and Testa).

Concerning the research method, a balanced distribution among the articles with qualitative methods (15) and the ones with quantitative methods (14) is observed, besides a meaningful article number classified as theoretical articles (10), and a minority of articles with mixed method (quali-quantitative). Among the articles with qualitative method, the case study (7) use stands out, meanwhile in the articles with quantitative method, there is a dispersion among structure equation modeling (4), multi-varied analysis (3), survey (3), among others.

The 42 articles analyzed showed 201 keywords, which were analyzed in terms of frequency. The keywords that were repeated ate least seven times were: sustainability (7), corporate social responsibility (8) e greenwashing (18).

In addition, each word was analyzed separately, and not each keyword, i.e., if a keyword had more than one word, each of these words ended up being accounted for alone. For instance, the social responsibility keyword was accounted for as two single words, social and responsibility. Thus, the 201 keywords identified totaled 374 different words, so that the 15 most frequently words found (that were repeated at least six times) were: CSR (7 repetitions), understood as corporate social responsibility, sustainability (11), green (12), responsibility (13), and, mainly, social and environmental (15 each), greenwashing (18) and corporate (21). All words found were used to form a cloud, performed in IRAMUTEQ program, as shown in Figure 2.

Revista de Gestão Social e Ambiental - RGSA, São Paulo, v. 11, n. 2, p. 54-72, maio/ago. 2017. 
Figure 2: Word cloud found in article keywords

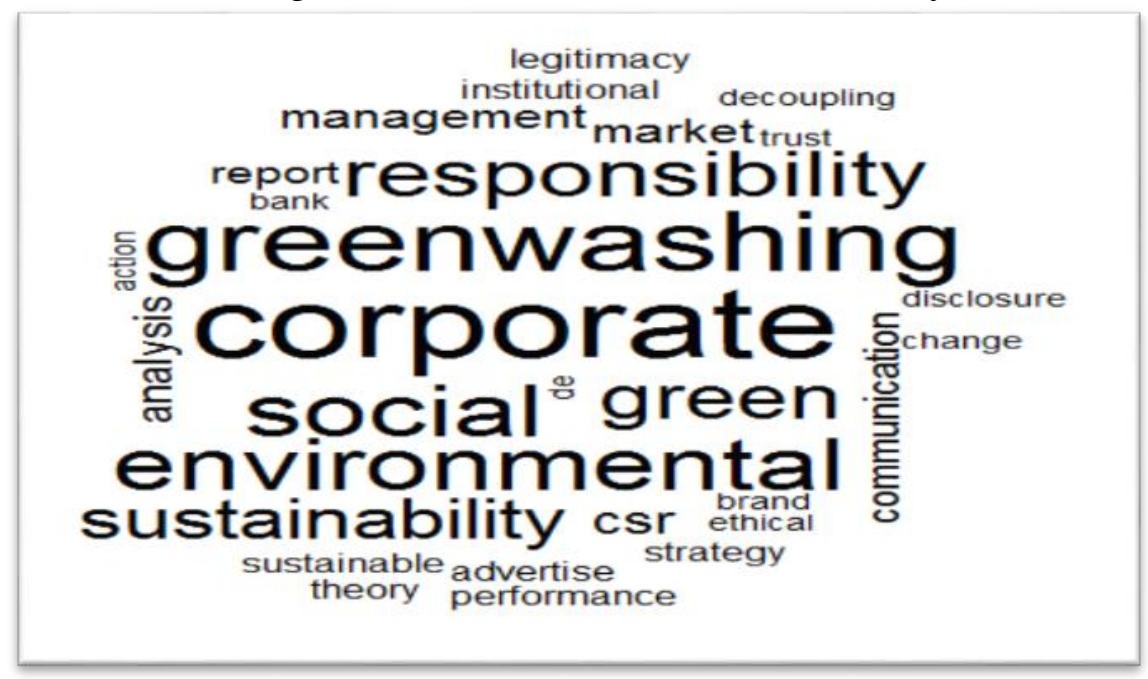

Source: Developed by the authors, using the IRAMUTEQ program.

Performing a similar analysis concerning the denominations used to identify the topics developed in the theoretical framework, 123 denominations were found, with around 300 different words, out of which some more frequent ones stood out, such as: legitimacy, organizations and sustainability, with six repetitions each; effect and ethical, repeating seven times each; social (8); communication and environmental, nine times each; as well as consumer and sustainability, ten tomes each; with green (12); greenwashing (20) and CSR (21) stood out (Figure 3).

Figure 3: Denomination cloud used to identify the topics developed in the theoretical framework

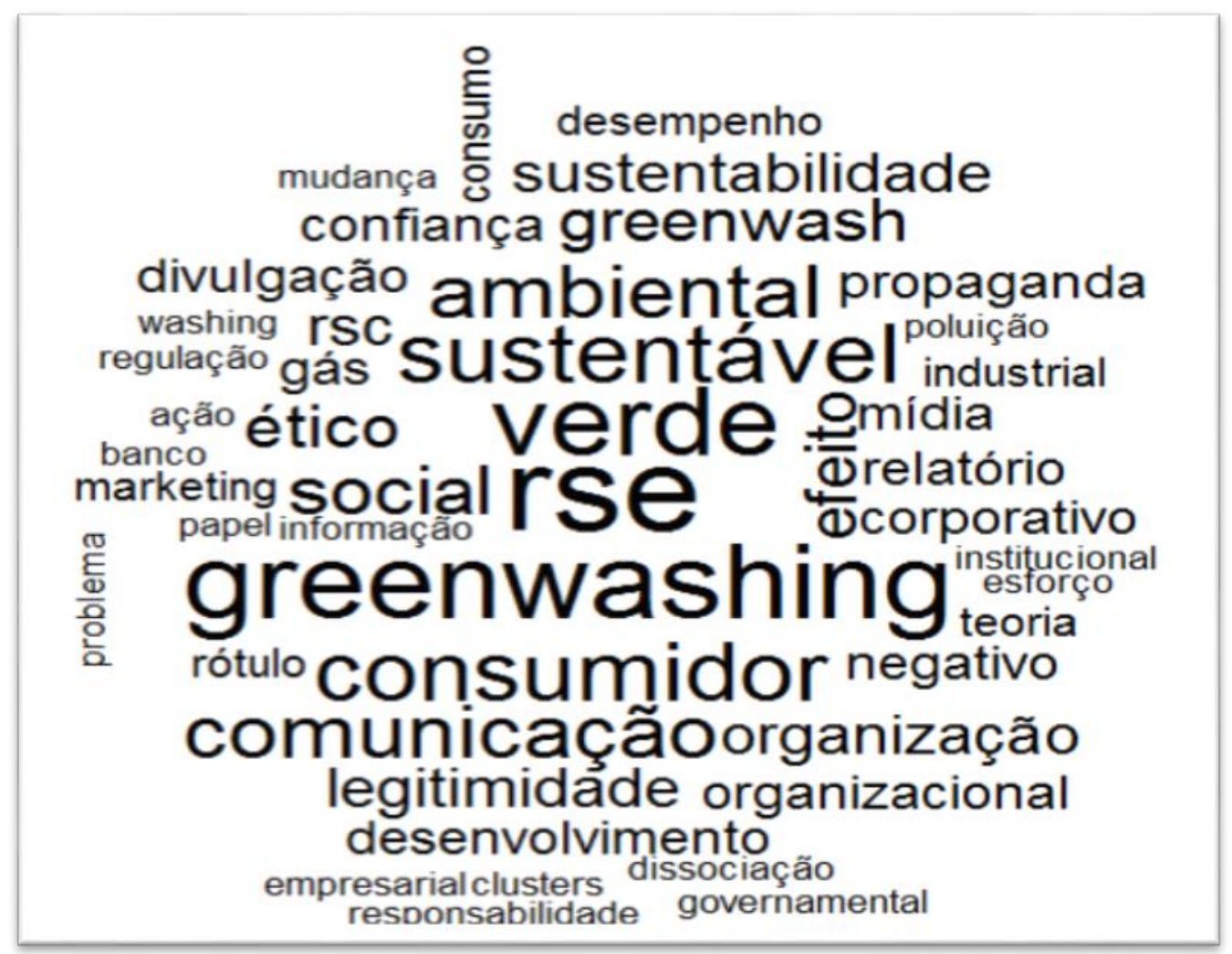

Source: Developed by the authors, using the IRAMUTEQ program. 
Concerning greenwashing specifically, the 42 articles analyzed can be rated in four different groups: the ones that only mention the term, the ones that approach it superficially, the ones that approach it as background and the ones that actually develop it (Table 2 ).

Table 2: Article analysis concerning the greenwashing discussion

\begin{tabular}{|c|c|c|c|}
\hline Only mention it & Approach it superficially & Approach it as background & Actually develop it \\
\hline 19 & 2 & 4 & 17 \\
\hline
\end{tabular}

Source: Developed by the authors.

Therefore, 19 articles only mention the term in some part(s) of the work, neither explaining nor deepening the subject. Among them, the majority presents a criticism about the trend of several organizations adopting such practice to promote themselves, in general and/or concerning sustainability or corporate social responsibility reports. Some articles still mention other points, such as the consumer skepticism issue as a consequence of this irresponsible practice by many organizations (3), besides using possible practices that could minimize the greenwashing problematic, such as organizational audit (2) or even government regulation (2).

Moreover, two articles develop the subject superficially (Table 3), also discussing the increasing use of such practice, and also mentioning either the consumer skepticism issue as a consequence of it (1) or the non-governmental organization role as possible incentive reduction agents that lead the organizations to adopt such posture (1). Another four articles (Table 4) develop the subject as background or grounding, although there is not great effort directed explicitly.

Table 3: Analysis of articles that approach the subject superficially

\begin{tabular}{|c|c|c|c|c|c|c|}
\hline Reference & $\mathbf{B}$ & Keywords & Purpose & $\begin{array}{c}\text { Conceptual } \\
\text { bases }\end{array}$ & Method & Results \\
\hline $\begin{array}{l}\text { LEBE; VRECKO. } \\
\text { Eco-labels and } \\
\text { Schemes: A } \\
\text { Requisitely } \\
\text { Holistic Proof of } \\
\text { Tourism's Social } \\
\text { Responsibility? } \\
\text { Systems Research } \\
\text { and Behavioral } \\
\text { Science Syst. Res. } \\
\text { A1 2014 }\end{array}$ & $\begin{array}{l}\mathrm{W} \\
\mathrm{C}\end{array}$ & $\begin{array}{l}\text { Tourism; project } \\
\text { management; } \\
\text { eco/sustainability- } \\
\text { certificates/ } \\
\text { schemes; green- } \\
\text { washing; } \\
\text { requisite holism; } \\
\text { systemic behaviour; } \\
\text { social responsibility }\end{array}$ & $\begin{array}{l}\text { Presenting a brief } \\
\text { analysis of the need and } \\
\text { benefits of the } \\
\text { ecological certificates } \\
\text { and sustainable schemes } \\
\text { to tourism (and } \\
\text { generally considered as } \\
\text { relevant social } \\
\text { responsibility evidences) }\end{array}$ & $\begin{array}{c}\text { Ethical, } \\
\text { responsible, } \\
\text { aware tourism } \\
\text { and what else? } \\
\text { Touristic } \\
\text { services } \\
\text { ecologically } \\
\text { certified; }\end{array}$ & $\begin{array}{c}\text { Theoretical } \\
\text { article }\end{array}$ & $\begin{array}{c}\text { The responsible } \\
\text { tourism is already a } \\
\text { mandatory competition } \\
\text { practice due to new } \\
\text { consumer value } \\
\text { irreversible growth } \\
\text { process }\end{array}$ \\
\hline $\begin{array}{c}\text { BERRONE; } \\
\text { FOSFURI; } \\
\text { GELABERT. } \\
\text { Does } \\
\text { Greenwashing Pay } \\
\text { Off? } \\
\text { Understanding the } \\
\text { Relationship } \\
\text { Between } \\
\text { Environmental } \\
\text { Actions and } \\
\text { Environmental } \\
\text { Legitimacy. J Bus } \\
\text { Ethics }^{\mathrm{Al}} 2015\end{array}$ & $S$ & $\begin{array}{l}\text { Environmental } \\
\text { management, } \\
\text { Institutional } \\
\text { Theory, } \\
\text { Greenwashing, } \\
\text { Signaling theory, } \\
\text { Nongovernmental } \\
\text { organizations }\end{array}$ & $\begin{array}{c}\text { Assessing the } \\
\text { heterogeneous sources in } \\
\text { environmental } \\
\text { legitimacy } \\
\text { environmental action } \\
\text { impacts }\end{array}$ & $\begin{array}{c}\text { Corporate } \\
\text { environmental } \\
\text { actions }\end{array}$ & $\begin{array}{c}\text { Quantitative } \\
- \\
\text { Correlations }\end{array}$ & $\begin{array}{l}\text { The environmental } \\
\text { patents enable } \\
\text { achieving legitimacy } \\
\text { and are the strongest } \\
\text { signal among } \\
\text { environmental actions. } \\
\text { Another environmental } \\
\text { actions increase } \\
\text { legitimacy when the } \\
\text { company has strong } \\
\text { credibility, but they } \\
\text { can damage the } \\
\text { company in other } \\
\text { circumstances. }\end{array}$ \\
\hline
\end{tabular}

Legend: B: Search base; P: Proquest; W: Web of Science; C: Capes; S: Scopus

Source: Developed by the authors. 
Table 4: Analysis of articles that approach the subject as background

\begin{tabular}{|c|c|c|c|c|c|c|}
\hline Reference & B & Keywords & Purpose & Conceptual bases & Method & Results \\
\hline $\begin{array}{l}\text { KLEBA. Adesão } \\
\text { voluntária e } \\
\text { Comportamento } \\
\text { Ambiental de } \\
\text { Empresas } \\
\text { Transnacionais do } \\
\text { Setor Químico no } \\
\text { Brasil. } \\
\text { Ambiente\&Socied } \\
\text { ade }^{\mathrm{B} 1} 2003\end{array}$ & $\begin{array}{l}\mathrm{S} \\
\mathrm{C}\end{array}$ & There are not & $\begin{array}{l}\text { Checking if corporate } \\
\text { voluntary adherence } \\
\text { offsets the local } \\
\text { environmental } \\
\text { standard unbalance or } \\
\text { if it is a deceiving } \\
\text { campaign to } \\
\text { demobilize the state } \\
\text { and public control } \\
\text { (greenwashing), as } \\
\text { well as containing } \\
\text { environmental } \\
\text { legislation } \\
\text { developments }\end{array}$ & $\begin{array}{l}\text { Industrial self- } \\
\text { regulation } \\
\text { function; From } \\
\text { reactive behavior } \\
\text { to a corporate } \\
\text { environmental } \\
\text { policy }\end{array}$ & $\begin{array}{l}\text { Qualitative - } \\
\text { Multiple } \\
\text { case study }\end{array}$ & $\begin{array}{l}\text { There is a difference } \\
\text { among the assessed } \\
\text { company environmental } \\
\text { policies, as some are } \\
\text { more and the others are } \\
\text { less consolidated. It is } \\
\text { concluded that the self- } \\
\text { regulation initiatives do } \\
\text { not reduce the } \\
\text { greenwashing, as they } \\
\text { foster meaningful } \\
\text { environmental protection } \\
\text { developments }\end{array}$ \\
\hline $\begin{array}{c}\text { PARGUEL; } \\
\text { BENÔIT- } \\
\text { MOREAU; } \\
\text { LARCENEUX. } \\
\text { How } \\
\text { Sustainability } \\
\text { Ratings Might } \\
\text { Deter } \\
\text { Greenwashing: A } \\
\text { Closer Look at } \\
\text { Ethical Corporate } \\
\text { Communication. J } \\
\text { Bus Ethics }{ }^{\mathrm{A} 1} 2011\end{array}$ & $\begin{array}{l}\mathrm{W} \\
\mathrm{C} \\
\mathrm{S}\end{array}$ & $\begin{array}{c}\text { Ethical } \\
\text { corporate, } \\
\text { marketing, CSR } \\
\text { Communication, } \\
\text { Attribution } \\
\text { theory, } \\
\text { Sustainability } \\
\text { ratings }\end{array}$ & $\begin{array}{c}\text { Assessing } \\
\text { sustainability ranking } \\
\text { influence potential in } \\
\text { CSR report consumer } \\
\text { responses }\end{array}$ & $\begin{array}{c}\text { CSR } \\
\text { communication } \\
\text { and ethical } \\
\text { organizational } \\
\text { marketing; CSR } \\
\text { communication } \\
\text { controversial } \\
\text { effects on } \\
\text { consumers; } \\
\text { Controllable } \\
\text { versus } \\
\text { uncontrollable } \\
\text { CRS } \\
\text { communication } \\
\end{array}$ & $\begin{array}{l}\text { Quantitative } \\
\text { - } \\
\text { Structuring } \\
\text { equation } \\
\text { modeling }\end{array}$ & $\begin{array}{l}\text { Empirical statement that } \\
\text { all sustainability } \\
\text { assessments have direct } \\
\text { effect on consumer } \\
\text { perception: by means of } \\
\text { hypothesis validation, it } \\
\text { is concluded that a good } \\
\text { rating has positive } \\
\text { impact on corporate } \\
\text { brand assessment, while } \\
\text { a poor rating causes } \\
\text { damages. }\end{array}$ \\
\hline $\begin{array}{c}\text { TESTA; } \\
\text { IRALDO; } \\
\text { TESSITORE; } \\
\text { FREY. Strategies } \\
\text { and approaches } \\
\text { green advertising: } \\
\text { an empirical } \\
\text { analysis of the } \\
\text { Italian context. } \\
\text { International } \\
\text { Journal of } \\
\text { Environment and } \\
\text { Sustainable } \\
\text { Development } \\
2011\end{array}$ & $\mathrm{~S}$ & $\begin{array}{l}\text { Environmental } \\
\text { advertising, } \\
\text { green } \\
\text { marketing, } \\
\text { green } \\
\text { communication. }\end{array}$ & $\begin{array}{l}\text { Analyzing the green } \\
\text { advertising } \\
\text { dissemination and } \\
\text { characteristics in } \\
\text { Italy's newspapers } \\
\text { from } 2007 \text { to the first } \\
\text { term of } 2008\end{array}$ & $\begin{array}{l}\text { Green advertising } \\
\text { approaches }\end{array}$ & $\begin{array}{c}\text { Quali- } \\
\text { quantitative } \\
- \\
\text { Documental } \\
\text { survey and } \\
\text { multidimens } \\
\text { ional } \\
\text { analysis }\end{array}$ & \\
\hline $\begin{array}{l}\text { MATEJEK; } \\
\text { GOSSLING. } \\
\text { Beyond } \\
\text { Legitimacy: A } \\
\text { Case Study in } \\
\text { BP's 'GGreen } \\
\text { Lashing'’. J Bus } \\
\text { Ethics }{ }^{\mathrm{Al}} 2014\end{array}$ & $\begin{array}{l}\mathrm{W} \\
\mathrm{C} \\
\mathrm{S}\end{array}$ & $\begin{array}{l}\text { Corporate } \\
\text { environmental } \\
\text { responsibility } \\
\text { Impression } \\
\text { management } \\
\text { Narrative } \\
\text { analysis } \\
\text { Corporate } \\
\text { communication } \\
\text { Image crisis }\end{array}$ & $\begin{array}{l}\text { Discussing the } \\
\text { legitimacy issue, and } \\
\text { specifically the } \\
\text { building, losing and } \\
\text { repairing process of } \\
\text { the environmental } \\
\text { legitimacy in } \\
\text { 'Deepwater Horizon' } \\
\text { case context }\end{array}$ & $\begin{array}{c}\text { Legitimacy } \\
\text { consequences and } \\
\text { priors }\end{array}$ & $\begin{array}{l}\text { Qualitative - } \\
\text { Case study }\end{array}$ & $\begin{array}{l}\text { The corporate greening } \\
\text { remains a potential } \\
\text { differentiation source } \\
\text { and even competitive } \\
\text { asset, however it must } \\
\text { have strong subsidies to } \\
\text { be authentic, enough to } \\
\text { avoid it from being } \\
\text { greenwashing }\end{array}$ \\
\hline
\end{tabular}

Legend: B: Search base; P: Proquest; W: Web of Science; C: Capes; S: Scopus Source: Developed by the authors.

Next, a critical analysis of the 17 articles that actually worked with greenwashing will be proceed, which, because of their importance, are arranged in a specific subtopic. 


\subsubsection{Analysis of articles that actually developed the greenwashing}

More importantly, 17 articles (Table 5) actually developed the greenwashing, discussing the subject in the theoretical framework and providing the proper grounding (concept survey and different reference crossing).

Analyzing specifically these 17 articles, it can be observed that eleven of them wore published in journals which rating, according to 2014 Qualis list, are A1, highlighting, once again, the Journal of Businesse Ethics, with ten articles, followed by three articles published in B1 rating journals. It should be emphasized that three publications were found in Brazilian journals. Beside that, almost all of these 17 articles were published among the years 2012 and 2015, with exception of only both (2003 e 2009).

Is was verified that 16 articles providing grounding on the subject, and seven also explore some hypothesis or proposition to be discussed by the article related to it. Still, among the main themes that support the discussions, in addition to the greenwashing itself, the environmental stand out socioenvironmental or sustainable responsibility of organizations, as well as sustainability present in at least half of the articles. Thus, it can be argued that the articles sought a contextualization of greenwashing as a response (albeit mistaken) by organizations to the new demands of the current competitive context.

\subsubsection{Classification regarding the objectives compared to the results obtained}

In relation to the objectives stipulated by the articles, it was analyzed that 13 articles present the greenwashing in the work general purpose, and two implicitly. Such purposes can be rated in two main points.

At first, there are six articles aimed at surveying or identifying the greenwashing, checking if specific environmental practices can be rated as such, if there is discrepancy between speech and practice, questioning the organization voluntary adherence and verifying the sustainability reports. Among the articles that had this objective, it is emphasized, however, that there was no consonance in the results, with half of the articles suggesting the actual existence or potential of the greenwashing practice by the organizations studied, and the other half verifying that such practice was not found in the objects of analysis. Such a stalemate, by itself, already indicates the need for more studies aimed at this line of research.

The second set, with seven articles, is aimed at some greenwashing aspects that can influence or suffer influence of the greenwashing practice, including market assessment, social media influence, and the government role, the pros and cons of this practice and the consumer trust impact. Among these articles, the results were diverse. First (4), it was pointed out that both government and laws and social media can contribute to reducing the practice of greenwashing by organizations, which can also occur through greater information and participation of society. Nonetheless, the articles also reinforced that the practice of greenwashing results from increased market demand for ecologically correct or sustainable positions by organizations. Meaning a certain counter-claim can be noted, in that the practice of greenwashing is the result of a - irresponsible - adaptation of organizations to the new demands of the market, at the same time as such collections can also contribute to undermining this practice.

Second (2), it was found that the practice of greenwashing negatively impact the financial performance of organizations. And finally (3), there was a negative impact of this practice on the consumer market, increasing both the confusion and the skepticism of the consumers as well as the risk perceived by them regarding the green images propagated by the organizations, as well as diminishing the trust related to them. Therefore, the results found in this second set of articles highlight possible actions to regulate or curb the practice of greenwashing, as well as highlight the negative consequences of this practice in the consumer market.

\subsubsection{Classification regarding the method, compared to the results obtained}

Concerning the method declared in the articles, it was observed a predominance of the quantitative method (7), follow by the theoretical article (6), besides the qualitative (3) and quali-quantitative method (1).

In the quantitative method (7), the modeling technique of structural equations (3) was highlighted, with an econometric model, an experiment, a focus group with hypothesis testing and a multivariate analysis. It is interesting to note that of these, three articles directed their investigations to China and one to the United States.

Revista de Gestão Social e Ambiental - RGSA, São Paulo, v. 11, n. 2, p. 54-72, maio/ago. 2017. 
In this sense, Chen and Chang (2012) focused their studies on Taiwanese consumers who purchased electronic products, suggesting that companies should reduce their greenwash behaviors to improve the ecological trust of their consumers. Du (2014), in turn, described that greenwashing practices are recurring in the country and investigated how the market values green actions by exploring the association between greenwashing, environmental performance, and market reactions. Guo, Tao, Li and Wang (2015) have focused on energy companies, where green-brand strategy has become important to increase competitive advantage. For this reason, the authors pointed out that greenwashing behaviors result in a crisis of confidence, as Chinese consumers increasingly prefer green products and energy brands. The authors also reported that in China there is pressure from customers and the government for greater environmental protection from the three power generation companies.

In contrast to the aforementioned articles, Wu and Shen (2013) studied the American banks, investigating the association between corporate social responsibility and financial performance, as well as raising the discussion to why banks are driven to get involved in social responsibility actions. Thus, the authors affirmed that social responsibility can facilitate brand differentiation, as well as use this advantage to increase net profit.

However, actions of social responsibility generate costs, which can contribute to the adoption of irresponsible behaviors by these institutions, who end up practicing greenwashing. Thus, the authors concluded that Corporate Social Responsibility is positively linked to financial performance and underscore the need for government to support institutions that adopt social responsibility practices.

In turn, Walker and Wan (2012) sought a better understanding of corporate communications about the environment and the performance and financial implications resulting therefrom. Based on the delineation of the differences between the sectors surveyed, the authors concluded that these results may differ according to the sector, but in general, the substantial actions neither hindered nor benefited the financial performance, but the symbolic actions were related to the decrease of the Financial performance, in other words, actions that were not put into practice, resulted in greenwashing and, therefore, disrupted the financial performance of companies. Testa, Boiral and Iraldo (2015) discussed the adoption of certifications such as ISO 14000 (environmental management standards) and EMAS (European Management and Audit System). They pointed out that, although institutional pressures from suppliers and shareholders strengthen the internationalization of proactive environmental practices, the influence of stakeholders (clients and industry associations) can support integration or encourage its superficial adoption, also leading to greenwashing.

Finally, by adopting another approach, Nyilasy, Gangadharbatla and Paladino (2013) concentrated their experimental studies on the investigation of the effects of green advertising and an organization's performance in relation to brand attitudes and consumer buying intentions.

Also the theoretical essays (6) had a significant presence, contributing to the elucidation of the theme, which denote the current and the evolution of the discussion about greenwashing. Among these, Laufer (2003) discussed the integrity of social and environmental responsibility reports and the challenges faced to ensure that they are the mirror of reality. It also emphasized that such reports need to be presented fairly and accurately and in accordance with the law, and also proposed a reform in the preparation of these reports in order to guarantee the non-occurrence of greenwashing. Similarly, Lyon and Montgomery (2013) also emphasized the importance of social accountability reports, as they are increasingly widespread, emphasizing the importance of dissociating behaviors when elaborating them, so that they are not just reports of facade. The authors also presented a theoretical framework for the understanding of corporate greenwashing, also highlighting how social media can contribute to the reduction of this practice. Finally, Pope and Waeraas (2015) also discussed the importance of sustainability reporting, arguing that, since these are often invisible to consumers, companies are more likely to "manufacture" them. Thus, the authors emphasized the importance of the existence of a classification by ranking for these companies and certifications, as well as defended the creation of surveillance groups.

In addition, Lovato (2013) addressed the discussion about the use of environmental sustainability only as a form of market appeal and analyzed how the attempt to control this practice has taken place in Brazil, also analyzing the legal principles that can and must be used to inhibit the practice of greenwashing. In agreement with the author, Markham, Khare and Beckman (2014) focused on analyzing the increase in the number of companies that have publicly promoted the environment from their operating practices or products. They pointed out that, by increasing the market for green products, consumers have been misled by 
some companies that have come to promote a false environmental benefit, and argue for the urgency of taking tangible measures to control the occurrence of greenwashing.

Finally, Oliveira, Santos and Hurtado (2015) specified their studies in the analysis of the product life cycle communication to stakeholders, since these are increasingly widespread in society, which raises doubts regarding the environmental performance of these companies and products. Having said this, they stressed the importance of communication in order to overcome the challenge of greenwashing.

In the qualitative method (3), there were all case studies. Of these, Destes, Lins and Silva (2009) focused on paper and pulp companies listed in the ISE (Corporate Sustainability Index), analyzing the level of environmental disclosure of these companies' sustainability reports. The choice of the object of analysis was justified because it is a sector whose activities are normally harmful to the environment or accumulate high risk of environmental accidents. Similarly, Turano, Cherman and Franca (2014) focused their studies on a large corporation that posed risks to the environment, analyzing the discrepancy between its discourse and its practice of sustainability. The authors highlighted evidence of greenwashing, in that the reports emphasized positive actions and disguised those of a negative nature. Still in this context, Ploeg and Vanclay (2013) sought to provide a mechanism to evaluate the veracity of corporate social responsibility reports, drawing up a list that, according to the authors, allows any reader to make a judgment. In addition, it would help organizations to produce more transparent reports.

Finally, the only one with a qualitative-quantitative method, Roulet and Toubol (2014) focused their studies on individuals and their liberal values, considering that responsibility would affect corporate behavior, ie how companies are prone to profit, so would social actors. Thus, the authors emphasized that the belief in favor of individual responsibility is motivated by the organization when it has the aspiration to do good, while the excessive preoccupation with competition and profit may cause the employees to take actions directed denoting the greenwashing.

\subsubsection{Indications of future research}

Based on the previous analyzes, a significant evolution of the research on greenwashing could be verified, since initially, most of the studies revolved around research on corporate sustainability reports and their implications (Laufer, 2003, Lins \& Silva 2009, Walker, 2012), even with the proposition about a checklist able to assess the accuracy of the information contained therein (Ploeg \& Vanclay, 2013). Later on, other perspectives have come to be covered, such as those related to the impacts that large corporations cause and suffer when practicing greenwashing (Chen \& Chang, 2012, Wu \& Shen, 2013, Du, 2014, Guo, Tao, Li \& Wang , 2015, Testa, Boiral \& Iraldo, 2015). In addition, different organizations, markets and localities were investigated, highlighting the plurality of the studies and the results found ou, without existing until then a prior replication effort.

In the meantime, new studies are suggested precisely in these directions, i.e., it seems possible to categorize in two strands the main directions suggested for future studies.

The first strand indicates a concern regarding the identification and / or investigation of the practice of greenwashing, mainly in order to contribute to its detection, with a view to possible actions to combat or inhibit it. Thus, it is expected that new studies will be able to verify what is being propagated by the organizations regarding the environmental actions, comparing if the discourse is compatible with the practice. New tools and / or mechanisms that facilitate or allow the detection of greenwashing by organizations are also required. In addition, a greater understanding of the influence of possible different regulatory actions and restraint of this practice is sought, whose investigation includes the role of several agents, such as suppliers, competitors, consumers, government, among others.

The second part, in turn, recommends a deeper understanding of the effects and consequences of this practice, whether in the market as a whole, in the society or in the consumer public. Thus, work that analyzes the impact of the practice of greenwashing on the green market in general (and its various variables) is encouraged, as well as on society's belief in ecologically correct organizational practices as a whole. More specifically, it is recommended to analyze the consequences of this practice on consumer behavior, identifying variables that can act as moderators or even mediators of this process.

Revista de Gestão Social e Ambiental - RGSA, São Paulo, v. 11, n. 2, p. 54-72, maio/ago. 2017. 
Table 5: Analysis of the articles that actually develop the theme

\begin{tabular}{|c|c|c|c|c|c|}
\hline Reference & Keywords & Purpose & Conceptual bases & Method & Results \\
\hline \begin{tabular}{|l} 
TURANO; \\
CHERMAN; \\
FRANCA. \\
Sustentabilida \\
de em uma \\
grande \\
corporação: \\
uma análise \\
da \\
discrepância \\
entre discurso \\
e prática. Rev. \\
Adm. \\
UFSM $^{\mathrm{B} 2} 2014$ \\
\end{tabular} & $\begin{array}{c}\text { Responsabilidad } \\
\text { e social (social } \\
\text { responsibility), } \\
\text { Desenvolviment } \\
\text { o sustentável } \\
\text { (sustainable } \\
\text { development), } \\
\text { Greenwash, } \\
\text { Sustentabilidade } \\
\text { (sustainability), } \\
\text { Estudo de caso } \\
\text { (Case Study) }\end{array}$ & $\begin{array}{l}\text { Analyzing the } \\
\text { discrepancy between } \\
\text { the sustainability } \\
\text { speech and practice in } \\
\text { a large corporation }\end{array}$ & $\begin{array}{c}\text { Social responsibility; } \\
\text { Sustainable development } \\
\text { and sustainability; } \\
\text { Sustainability speech in } \\
\text { organizations }\end{array}$ & $\begin{array}{l}\text { Qualitative - } \\
\text { Case study }\end{array}$ & $\begin{array}{l}\text { Sustainability report overestimates } \\
\text { the positive actions and minimizes } \\
\text { the negative impacts, and it is } \\
\text { permeated by vague and subjective } \\
\text { information, which do not enable an } \\
\text { objective analysis of such statement } \\
\text { legitimacy (greenwash). It is, thus, a } \\
\text { partial and biased speech. It is } \\
\text { corroborated by the media, which } \\
\text { states that the greatest share of the } \\
\text { value invested in CSR actions was } \\
\text { not employed in the caused damage } \\
\text { prevention or remedy, but in green } \\
\text { makeup activities (greenwash) }\end{array}$ \\
\hline \begin{tabular}{|l} 
LINS; \\
SILVA. \\
Responsabilid \\
ade Sócio- \\
Ambiental ou \\
Greenwash: \\
Uma \\
Avaliação \\
com Base nos \\
Relatórios de \\
Sustentabilida \\
de Ambiental. \\
Sociedade, \\
Contabilidade \\
e Gestão \\
2009 \\
\end{tabular} & $\begin{array}{c}\text { Evidenciação } \\
\text { (disclosure), } \\
\text { Responsabilidad } \\
\text { e ambiental } \\
\text { (environmental } \\
\text { responsibility), } \\
\text { Relatório } \\
\text { ambiental } \\
\text { (environmental } \\
\text { report). }\end{array}$ & $\begin{array}{c}\text { Assessing the } \\
\text { sustainability report } \\
\text { evidencing and } \\
\text { transparence level } \\
\text { issued by pulp and } \\
\text { paper market } \\
\text { companies. }\end{array}$ & $\begin{array}{l}\text { Corporate sustainability } \\
\text { index; Socio- } \\
\text { environmental } \\
\text { responsibility disclosure; } \\
\text { Socio-environmental } \\
\text { responsibility disclosure } \\
\text { or Greenwash? }\end{array}$ & $\begin{array}{l}\text { Qualitative - } \\
\text { Multiple case } \\
\text { study }\end{array}$ & $\begin{array}{l}\text { The disclosure and transparence level } \\
\text { assessment of sustainability reports } \\
\text { issued by the companies showed two } \\
\text { companies with good scores, and one } \\
\text { with lower score, pointing the reports } \\
\text { as an effective company } \\
\text { environmental management } \\
\text { disclosure instrument. }\end{array}$ \\
\hline \begin{tabular}{|l} 
PLOEG; \\
VANCLAY. \\
Credible \\
claim or \\
corporate \\
spin? A \\
checklist to \\
evaluate \\
corporate \\
sustainability \\
reports. \\
Journal of \\
Environmenta \\
1 Assessment \\
Policy and \\
Management \\
${ }^{\mathrm{B}} 2013$ \\
\end{tabular} & $\begin{array}{l}\text { Corporate social } \\
\text { responsibility, } \\
\text { business and the } \\
\text { environment, } \\
\text { sustainability } \\
\text { reporting } \\
\text { guidelines, } \\
\text { green washing, } \\
\text { sustainability } \\
\text { indicators, } \\
\text { corporate social } \\
\text { performance }\end{array}$ & $\begin{array}{c}\text { Introducing a } \\
\text { sustainable report } \\
\text { verification checklist, } \\
\text { based on GRI (Global } \\
\text { Reporting Initiative) }\end{array}$ & $\begin{array}{l}\text { Sustainable reports; } \\
\text { Sustainable report } \\
\text { guide/guidance; A } \\
\text { checklist to verify the } \\
\text { sustainable } \\
\text { organizational statements }\end{array}$ & $\begin{array}{l}\text { Qualitative - } \\
\text { Documental } \\
\text { analysis and } \\
\text { Case study }\end{array}$ & $\begin{array}{l}\text { Checklist development and } \\
\text { application in an international gas } \\
\text { organization, which showed } \\
\text { inadequacies in the report submitted, } \\
\text { with greenwashing evidence }\end{array}$ \\
\hline $\begin{array}{l}\text { WALKER; } \\
\text { WAN. The } \\
\text { Harm of } \\
\text { Symbolic } \\
\text { Actions and } \\
\text { Green- } \\
\text { Washing: } \\
\text { Corporate } \\
\text { Actions and } \\
\text { Communicati } \\
\text { ons on } \\
\text { Environmenta } \\
1 \text { Performance } \\
\text { and Their } \\
\text { Financial } \\
\text { Implications. } \\
\text { J Bus Ethics } \\
\text { 2012 } \\
\end{array}$ & $\begin{array}{c}\text { Corporate } \\
\text { environmental } \\
\text { performance, } \\
\text { Corporate } \\
\text { websites, } \\
\text { Green- } \\
\text { highlighting, } \\
\text { Green-washing, } \\
\text { Substantive } \\
\text { actions, } \\
\text { Symbolic } \\
\text { actions }\end{array}$ & $\begin{array}{l}\text { Which environmental } \\
\text { subjects the companies } \\
\text { are specifically } \\
\text { approaching? How do } \\
\text { such subjects differ } \\
\text { among industries? Are } \\
\text { the symbolic and } \\
\text { financially substantial } \\
\text { actions beneficial? Is } \\
\text { the greenwashing, } \\
\text { assessed by the } \\
\text { difference between the } \\
\text { symbolic and the } \\
\text { substantial action, } \\
\text { and/or green } \\
\text { highlighting, assessed } \\
\text { as the combination of } \\
\text { the two, worthwhile? }\end{array}$ & $\begin{array}{l}\text { Substantive actions; } \\
\text { Symbolic actions; } \\
\text { Greenwashing; Green- } \\
\text { Highlighting; }\end{array}$ & $\begin{array}{l}\text { Quantitative - } \\
\text { Structural } \\
\text { Equation } \\
\text { Modeling }\end{array}$ & $\begin{array}{l}\text { The greenhouse effect gas } \\
\text { management and environmental } \\
\text { conservation are deeply relevant } \\
\text { issues to companies, regardless of the } \\
\text { market. The forest market overcame } \\
\text { the energy market and the industries } \\
\text { may differ concerning the } \\
\text { environmental rating they are willing } \\
\text { to focus on. Some environmental } \\
\text { actions were rated as substantial and } \\
\text { neither harm nor benefit the company } \\
\text { finances. On the other hand, the } \\
\text { symbolic actions are related to the } \\
\text { financial performance decrease, } \\
\text { showing that the greenwashing } \\
\text { damages the companies financially. }\end{array}$ \\
\hline \begin{tabular}{|c|} 
LYON; \\
MONTGOM \\
ERY. \\
Tweetjacked: \\
The Impact of \\
Social Media \\
on Corporate \\
Greenwash. J \\
\end{tabular} & $\begin{array}{l}\text { Corporate social } \\
\text { responsibility, } \\
\text { decoupling } \\
\text { Greenwash, } \\
\text { information } \\
\text { disclosure, } \\
\text { Legitimacy, } \\
\text { Social media } \\
\end{array}$ & $\begin{array}{l}\text { How will the social } \\
\text { media uprising impact } \\
\text { the corporate } \\
\text { greenwash reach? How } \\
\text { will it change the } \\
\text { channels through } \\
\text { which the } \\
\text { organizations }\end{array}$ & $\begin{array}{l}\text { Legitimacy, dissociation } \\
\text { and greenwash; } \\
\text { Information economies, } \\
\text { broadcast and greenwash; } \\
\text { Communication and the } \\
\text { media role; Greenwash } \\
\text { and the social media; The } \\
\text { social media use by }\end{array}$ & $\begin{array}{c}\text { Theoretical } \\
\text { article }\end{array}$ & $\begin{array}{l}\text { As the CSR activities become more } \\
\text { widely used, the greenwash is a } \\
\text { growing problem, causing increasing } \\
\text { consumer skepticism about corporate } \\
\text { environmentalism and threatening the } \\
\text { communication credibility. However, } \\
\text { the social media uprising shall enable } \\
\text { the corporate greenwash decrease. }\end{array}$ \\
\hline
\end{tabular}




\begin{tabular}{|c|c|c|c|c|c|}
\hline $\begin{array}{c}\text { Bus Ethics }^{\mathrm{A} 1} \\
2013\end{array}$ & & $\begin{array}{c}\text { communicate on their } \\
\text { environmental } \\
\text { performance? }\end{array}$ & \begin{tabular}{|c|} 
stakeholders to mitigate \\
the corporate greenwash; \\
The corporate social \\
media use for \\
environmental \\
communication
\end{tabular} & & \\
\hline \begin{tabular}{c|} 
CHEN; \\
CHANG. \\
Greenwash \\
and Green \\
Trust: The \\
Mediation \\
Effects of \\
Green \\
Consumer \\
Confusion \\
and Green \\
Perceived \\
Risk. J Bus \\
Ethics ${ }^{\mathrm{A1}}$ 2012 \\
\end{tabular} & $\begin{array}{l}\text { Greenwash } \\
\text { Green trust } \\
\text { Green consumer } \\
\text { confusion } \\
\text { Green perceived } \\
\text { risk } \\
\text { Green } \\
\text { marketing }\end{array}$ & $\begin{array}{l}\text { Exploring the } \\
\text { greenwash influence in } \\
\text { green trust and } \\
\text { discussing the } \\
\text { mediation role of green } \\
\text { consumer confusion } \\
\text { and green perceived } \\
\text { risk }\end{array}$ & $\begin{array}{l}\text { The greenwash positive } \\
\text { effect in green consumer } \\
\text { confusion and green } \\
\text { perceived risk; The } \\
\text { greenwash negative } \\
\text { effect in green trust; The } \\
\text { green consumer } \\
\text { confusion negative effect } \\
\text { in green trust; The green } \\
\text { perceived risk negative } \\
\text { effect in green trust }\end{array}$ & $\begin{array}{l}\text { Quantitative - } \\
\text { Structural } \\
\text { equation } \\
\text { survey and } \\
\text { modeling }\end{array}$ & $\begin{array}{l}\text { Greenwash is related negatively to } \\
\text { green trust. The green consumer } \\
\text { confusion and the green perceived } \\
\text { risk mediate negatively the } \\
\text { relationship between greenwash and } \\
\text { green trust. Moreover, the greenwash } \\
\text { is positively related to green } \\
\text { consumer confusion and green } \\
\text { perceived risk, which impact } \\
\text { negatively the green trust (impacting, } \\
\text { thus, directly and indirectly). }\end{array}$ \\
\hline \begin{tabular}{c|} 
ROULET; \\
TOUBOL. \\
The \\
Intentions \\
with Which \\
the Road is \\
Paved: \\
Attitudes to \\
Liberalism as \\
Determinants \\
of \\
Greenwashing \\
J Bus \\
Ethics \\
C1 $^{\mathrm{A}} 2014$ \\
\end{tabular} & $\begin{array}{l}\text { Corporate social } \\
\text { actions } \\
\text { Greenwashing } \\
\text { Economic } \\
\text { liberalism } \\
\text { Competition } \\
\text { Individual } \\
\text { responsibility } \\
\text { Country-level } \\
\text { institutions }\end{array}$ & $\begin{array}{l}\text { Discussing both beliefs } \\
\text { impact on how CSR is } \\
\text { developed (belief in } \\
\text { competition beneficial } \\
\text { role and individual } \\
\text { responsibility } \\
\text { prevalence), which } \\
\text { play a major role in } \\
\text { liberal economic } \\
\text { system development }\end{array}$ & $\begin{array}{l}\text { Greenwashing; Economic } \\
\text { liberalism and shared } \\
\text { beliefs }\end{array}$ & $\begin{array}{l}\text { Quali- } \\
\text { quantitative - } \\
\text { Focus group } \\
\text { and } \\
\text { Hypotheses } \\
\text { test }\end{array}$ & $\begin{array}{l}\text { Paradoxically, in countries where the } \\
\text { belief in competition virtues is } \\
\text { strong, the organizations are more } \\
\text { likely to practice the greenwash, } \\
\text { while in countries where the belief in } \\
\text { individual responsibility is more } \\
\text { prevalent, the likelihood is lower. }\end{array}$ \\
\hline $\begin{array}{l}\text { DU. How the } \\
\text { Market } \\
\text { Values } \\
\text { Greenwashing } \\
\text { ? Evidence } \\
\text { from China. J } \\
\text { Bus Ethics } \\
2014\end{array}$ & \begin{tabular}{|c} 
Greenwashing, \\
Corporate \\
environmental \\
Performance, \\
Cumulative \\
abnormal \\
returns (CAR), \\
Media \\
Coverage, The \\
Global \\
Reporting \\
Initiative (GRI), \\
The competitive \\
effect, The \\
contagious \\
effect, \\
Environmental \\
Wrongdoer, \\
China \\
\end{tabular} & $\begin{array}{l}\text { Surveying how the } \\
\text { market assesses the } \\
\text { greenwashing and } \\
\text { examining if the } \\
\text { organization } \\
\text { environmental } \\
\text { performance can } \\
\text { explain market } \\
\text { different and } \\
\text { asymmetric reactions } \\
\text { concerning } \\
\text { environmentally } \\
\text { friendly and unfriendly } \\
\text { organizations }\end{array}$ & $\begin{array}{l}\text { Institutional fund } \\
\text { (Greenwashing; } \\
\text { Organization } \\
\text { environmental } \\
\text { performance) }\end{array}$ & $\begin{array}{l}\text { Quantitative - } \\
\text { Multi-varied } \\
\text { test }\end{array}$ & $\begin{array}{l}\text { Greenwashing and cumulative } \\
\text { abnormal returns (CAR) have a } \\
\text { meaningful negative association, } \\
\text { while the organizational } \\
\text { environmental performance has a } \\
\text { significant positive association with } \\
\text { CAR concerning the greenwashing } \\
\text { exposure. }\end{array}$ \\
\hline $\begin{array}{c}\text { LAUFER. } \\
\text { Social } \\
\text { Accountabilit } \\
\text { y and } \\
\text { Corporate } \\
\text { Greenwashing } \\
\text { J Bus } \\
\text { Ethics }^{\mathrm{A} 1} 2003\end{array}$ & There are not & $\begin{array}{l}\text { Arguing that the } \\
\text { problems and } \\
\text { challenges related to } \\
\text { fair and accurate } \\
\text { organizational social } \\
\text { publicizing assurance } \\
\text { are based on the ones } \\
\text { with corporate follow- } \\
\text { up as per the } \\
\text { legislation } \\
\end{array}$ & $\begin{array}{l}\text { Following the rules; } \\
\text { Social accountability and } \\
\text { legitimacy management; } \\
\text { Greenwashing; Social } \\
\text { accountability survey and } \\
\text { voluntary notification } \\
\text { limits; Beyond verified } \\
\text { publicizing: tripartism }\end{array}$ & $\begin{array}{l}\text { Theoretical } \\
\text { article }\end{array}$ & $\begin{array}{l}\text { The problems and challenges related } \\
\text { to fair and accurate CSR publicizing } \\
\text { assurance are based on those } \\
\text { corporate follow-ups in compliance } \\
\text { with the legislation. The similarities } \\
\text { and convergence points between } \\
\text { social publicizing and corporate } \\
\text { compliance are also discussed, along } \\
\text { with reform proposals. }\end{array}$ \\
\hline $\begin{array}{l}\text { MARKHAM; } \\
\text { KHARE; } \\
\text { BECKMAN. } \\
\text { Greenwashing } \\
\text { : a proposal to } \\
\text { restrict its } \\
\text { spread. } \\
\text { Journal of } \\
\text { Environmenta } \\
1 \text { Assessment } \\
\text { Policy and } \\
\text { Management }{ }^{\mathrm{B}} \\
{ }^{1} 2014 \\
\end{array}$ & $\begin{array}{l}\text { Sustainability, } \\
\text { greenwashing, } \\
\text { green products, } \\
\text { environmental } \\
\text { benefits }\end{array}$ & $\begin{array}{l}\text { Discussing the urgency } \\
\text { of approaching our fast } \\
\text { deteriorating } \\
\text { environmental } \\
\text { demands that tangible } \\
\text { steps are taken to } \\
\text { control greenwashing } \\
\text { occurrences, assessing } \\
\text { the government merits } \\
\text { and drawbacks to take } \\
\text { over an active role in } \\
\text { this regulation } \\
\end{array}$ & $\begin{array}{l}\text { How to locate the } \\
\text { greenwashing; Why do } \\
\text { organizations perform } \\
\text { greenwashing and why is } \\
\text { it a public interest } \\
\text { subject? Governmental } \\
\text { efforts to control } \\
\text { greenwashing; } \\
\text { Alternatives to } \\
\text { governmental regulation; } \\
\text { How to limit the } \\
\text { greenwashing growth }\end{array}$ & $\begin{array}{l}\text { Theoretical } \\
\text { article }\end{array}$ & $\begin{array}{l}\text { Due to the potential cost of not being } \\
\text { seen as committed with sustainable } \\
\text { practices, and also due to the } \\
\text { consumer check difficulty, the } \\
\text { greenwashing arises as a response to } \\
\text { market demands to achieve greater } \\
\text { public endorsement to sustainability. } \\
\text { It has the potential to limit market } \\
\text { progress in adopting sustainable } \\
\text { practices, enabling the ecofriendly } \\
\text { product market erosion. Thus, the } \\
\text { government has to assume greater } \\
\text { responsibility concerning }\end{array}$ \\
\hline
\end{tabular}




\begin{tabular}{|c|c|c|c|c|c|}
\hline & & & & & $\begin{array}{l}\text { greenwashing checking and } \\
\text { regulation }\end{array}$ \\
\hline $\begin{array}{c}\text { NYILASY; } \\
\text { GANGADHA } \\
\text { RBATLA; } \\
\text { PALADINO. } \\
\text { Perceived } \\
\text { Greenwashing } \\
\text { : The } \\
\text { Interactive } \\
\text { Effects of } \\
\text { Green } \\
\text { Advertising } \\
\text { and Corporate } \\
\text { Environmenta } \\
1 \text { Performance } \\
\text { on Consumer } \\
\text { Reactions. J } \\
\text { Bus Ethics } \\
2013 \\
\end{array}$ & $\begin{array}{l}\text { Greenwashing, } \\
\text { Environmental } \\
\text { messages, } \\
\text { Green } \\
\text { messages, } \\
\text { Attribution } \\
\text { theory, } \\
\text { Corporate } \\
\text { advertising, } \\
\text { Green } \\
\text { advertising }\end{array}$ & $\begin{array}{l}\text { Surveying the effects } \\
\text { of green advertising } \\
\text { and organizational } \\
\text { environmental } \\
\text { performance on brand } \\
\text { attitudes and purchase } \\
\text { intention }\end{array}$ & $\begin{array}{c}\text { Green advertising, CSR } \\
\text { and consumer responses; } \\
\text { Organization } \\
\text { environmental } \\
\text { performance and } \\
\text { consumer responses; } \\
\text { Interaction between green } \\
\text { advertising and } \\
\text { organizational } \\
\text { environmental } \\
\text { performance; Assignment } \\
\text { theory }\end{array}$ & $\begin{array}{l}\text { Quantitative - } \\
\text { Experiment }\end{array}$ & $\begin{array}{l}\text { The negative effect of an } \\
\text { organization low performance in } \\
\text { brand attitudes becomes stronger } \\
\text { before the green advertising, } \\
\text { compared to general organizational } \\
\text { advertising and non-advertising. } \\
\text { Moreover, when the organizational } \\
\text { environmental performance is high, } \\
\text { both green and general advertisings } \\
\text { result in more non-favorable brand } \\
\text { attitudes than when there is no } \\
\text { advertising }\end{array}$ \\
\hline $\begin{array}{l}\text { WU; SHEN. } \\
\text { Corporate } \\
\text { social } \\
\text { responsibility } \\
\text { in the banking } \\
\text { industry: } \\
\text { Motives and } \\
\text { financial } \\
\text { performance. } \\
\text { Journal of } \\
\text { Banking \& } \\
\text { Finance } \\
2013 \\
\end{array}$ & $\begin{array}{l}\text { Corporate social } \\
\text { responsibility } \\
\text { Strategic motive } \\
\text { Altruistic } \\
\text { motive } \\
\text { Extended } \\
\text { Heckman two- } \\
\text { stage model }\end{array}$ & $\begin{array}{l}\text { Assessing the } \\
\text { relationship between } \\
\text { CSR and financial } \\
\text { performance in the } \\
\text { banking market, and } \\
\text { also the reason that } \\
\text { fosters banks to } \\
\text { perform the CSR }\end{array}$ & $\begin{array}{l}\text { CSR motivations and } \\
\text { banking profitability } \\
\text { function; CSR index } \\
\text { development }\end{array}$ & $\begin{array}{l}\text { Quantitative - } \\
\text { Econometric } \\
\text { template }\end{array}$ & $\begin{array}{l}\text { CSR can enable the brand } \\
\text { highlighting for strategic and } \\
\text { altruistic banks, but not to the ones } \\
\text { that perform greenwashing. } \\
\text { Depending on the guiding motives, } \\
\text { the CSR can generate positive, } \\
\text { uncertain or non-influential effects on } \\
\text { revenues, but the first one is the most } \\
\text { frequent }\end{array}$ \\
\hline $\begin{array}{l}\text { POPE; } \\
\text { WAERAAS. } \\
\text { CSR-Washing } \\
\text { is Rare: A } \\
\text { Conceptual } \\
\text { Framework, } \\
\text { Literature } \\
\text { Review, and } \\
\text { Critique. J } \\
\text { Bus Ethics } \\
2015\end{array}$ & $\begin{array}{l}\text { Corporate social } \\
\text { responsibility, } \\
\text { Greenwashing, } \\
\text { CSR and } \\
\text { decoupling, } \\
\text { CSR } \\
\text { communication, } \\
\text { CSR } \\
\text { performance, } \\
\text { CSR literature } \\
\text { review }\end{array}$ & $\begin{array}{l}\text { Performing a literature } \\
\text { review on the empiric } \\
\text { evidence for and } \\
\text { against each of the five } \\
\text { conditions that enable } \\
\text { the CSR - washing } \\
\text { occurrence }\end{array}$ & $\begin{array}{l}\text { CSR-washing terms, } \\
\text { limitations, scope and } \\
\text { method; Joint theoretical } \\
\text { framework and scoring } \\
\text { methodology; CSR- } \\
\text { washing conditions; Is } \\
\text { CSR-washing rare? }\end{array}$ & $\begin{array}{l}\text { Theoretical } \\
\text { article }\end{array}$ & $\begin{array}{l}\text { Several conditions are highly } \\
\text { contingent, letting CSR-washing as a } \\
\text { complex and fragile result. That goes } \\
\text { against the general public dominant } \\
\text { perception, including activists and a } \\
\text { vocal academic contingent, that the } \\
\text { CSR-washing success is excessive. }\end{array}$ \\
\hline $\begin{array}{l}\text { GUO; TAO; } \\
\text { LI; WANG. } \\
\text { A Path } \\
\text { Analysis of } \\
\text { Greenwashing } \\
\text { in a Trust } \\
\text { Crisis Among } \\
\text { Chinese } \\
\text { Energy } \\
\text { Companies: } \\
\text { The Role of } \\
\text { Brand } \\
\text { Legitimacy } \\
\text { and Brand } \\
\text { Loyalty. J } \\
\text { Bus Ethics } \\
2015 \\
\end{array}$ & $\begin{array}{l}\text { Greenwashing, } \\
\text { Energy brands, } \\
\text { Decoupling, } \\
\text { Legitimacy, } \\
\text { Brand loyalty, } \\
\text { Brand trust }\end{array}$ & $\begin{array}{l}\text { Evidencing an energy } \\
\text { brand decoupling path } \\
\text { from the green promise } \\
\text { to the green energy } \\
\text { brand trust and the } \\
\text { brand legitimacy and } \\
\text { loyalty role }\end{array}$ & $\begin{array}{c}\text { Greenwashing; } \\
\text { Institutional theory } \\
\text { decoupling; Green energy } \\
\text { brand legitimacy; Green } \\
\text { energy brand trust }\end{array}$ & $\begin{array}{l}\text { Quantitative - } \\
\text { Structural } \\
\text { equation } \\
\text { modeling and } \\
\text { Regression } \\
\text { template }\end{array}$ & $\begin{array}{l}\text { The green promise not only has a } \\
\text { direct negative effect on the green } \\
\text { energy brand trust, but also has an } \\
\text { indirect influence by means of the } \\
\text { green energy brand legitimacy } \\
\text { mediation vital role. Moreover, the } \\
\text { brand loyalty is a moderating factor } \\
\text { and can relieve the brand trust crisis. }\end{array}$ \\
\hline
\end{tabular}




\begin{tabular}{|c|c|c|c|c|c|}
\hline $\begin{array}{c}\text { TESTA; } \\
\text { BOIRAL; } \\
\text { IRALDO. } \\
\text { Internalizatio } \\
\text { n of } \\
\text { Environmenta } \\
\text { 1 Practices } \\
\text { and } \\
\text { Institutional } \\
\text { Complexity: } \\
\text { Can } \\
\text { Stakeholders } \\
\text { Pressures } \\
\text { Encourage } \\
\text { Greenwashing } \\
\text { ? J Bus } \\
\text { Ethics }{ }^{\mathrm{A} 1} 2015 \\
\end{array}$ & $\begin{array}{c}\text { Environmental } \\
\text { management } \\
\text { system, } \\
\text { Environmental } \\
\text { strategy, } \\
\text { Greenwashing, } \\
\text { Institutional } \\
\text { Complexity, } \\
\text { Stakeholders }\end{array}$ & $\begin{array}{l}\text { Analyzing the } \\
\text { underlying determining } \\
\text { factors to the proactive } \\
\text { environmental } \\
\text { management } \\
\text { internalization by } \\
\text { certified environmental } \\
\text { management systems } \\
\text { (as set forth in ISO } \\
\text { 14001) }\end{array}$ & $\begin{array}{l}\text { The heterogeneous } \\
\text { environmental } \\
\text { management system } \\
\text { internalization; } \\
\text { Institutional complexity } \\
\text { and corporate strategy }\end{array}$ & $\begin{array}{l}\text { Quantitative - } \\
\text { Non-linear } \\
\text { regression }\end{array}$ & $\begin{array}{l}\text { Even though institutional pressures } \\
\text { reinforce proactive environmental } \\
\text { practices internalization, the } \\
\text { stakeholder influence can support } \\
\text { such practice integration or stimulate } \\
\text { its superficial adoption }\end{array}$ \\
\hline $\begin{array}{l}\text { OLIVEIRA; } \\
\text { SANTOS; } \\
\text { HURTADO. } \\
\text { A } \\
\text { comunicação } \\
\text { da ACV: a } \\
\text { necessidade } \\
\text { de } \\
\text { diretrizes para } \\
\text { evitar o } \\
\text { Greenwashing } \\
\text {. Espacios } \\
2015 \\
\end{array}$ & $\begin{array}{c}\text { Análise do Ciclo } \\
\text { de vida } \\
\text { (Lifecycle } \\
\text { analysis), } \\
\text { Comunicação } \\
\text { (Communicatio } \\
\text { n), } \\
\text { Greenwashing }\end{array}$ & $\begin{array}{l}\text { Discussing how the } \\
\text { companies are } \\
\text { decoupling the } \\
\text { Lifecycle Analysis to a } \\
\text { market strategy are } \\
\text { reporting their results } \\
\text { before the stakeholders }\end{array}$ & $\begin{array}{l}\text { Sustainable development; } \\
\text { Lifecycle Assessment } \\
\text { (LCA); LCA reporting by } \\
\text { the companies } \\
\text { (greenwashing; } \\
\text { guidelines) }\end{array}$ & $\begin{array}{l}\text { Theoretical } \\
\text { article }\end{array}$ & $\begin{array}{l}\text { Due to lack of a general and clear } \\
\text { understanding concerning the LCA } \\
\text { methodology and its information } \\
\text { reporting guidelines, it is required } \\
\text { that the companies are increasingly } \\
\text { more careful with their corporate } \\
\text { communication, in order to assure the } \\
\text { full understanding, preventing that } \\
\text { the information is vague and generic } \\
\text { (greenwashing evidence), as the } \\
\text { doubts concerning the company and } \\
\text { product environmental performance } \\
\text { are still usual. }\end{array}$ \\
\hline $\begin{array}{c}\text { LOVATO. } \\
\text { Greenwashing } \\
\text { no Brasil } \\
\text { quando a } \\
\text { sustentabilida } \\
\text { de ambiental } \\
\text { se resume a } \\
\text { um rótulo. } \\
\text { Revista } \\
\text { Eletrônica do } \\
\text { Curso de } \\
\text { Direito/UFS } \\
\mathrm{M}^{\mathrm{B} 4} 2013\end{array}$ & $\begin{array}{l}\text { Greenwashing, } \\
\text { Publicidade } \\
\text { (Advertising), } \\
\text { Sustentabilidade } \\
\text { ambiental } \\
\text { (Environmental } \\
\text { sustainability) }\end{array}$ & $\begin{array}{l}\text { Approaching the } \\
\text { greenwashing from the } \\
\text { post-modern society } \\
\text { paradigm, centered by } \\
\text { consumption relations, } \\
\text { and analyzing how the } \\
\text { current market found in } \\
\text { the environmental } \\
\text { sustainability concept a } \\
\text { way to disguise the } \\
\text { irresponsible nature } \\
\text { use consequences }\end{array}$ & $\begin{array}{l}\text { The post-modern society } \\
\text { consumption and the man } \\
\text { and nature decoupling; } \\
\text { Greenwashing - the } \\
\text { consumer expectations } \\
\text { and guilt as misleading } \\
\text { advertising target: The } \\
\text { greenwashing (self-) } \\
\text { regulation attempt in } \\
\text { Brazil }\end{array}$ & $\begin{array}{l}\text { Theoretical } \\
\text { article }\end{array}$ & $\begin{array}{l}\text { Greenwashing discussion under a } \\
\text { sociological approach on current } \\
\text { population's consumerist behavior, } \\
\text { arguing that the consumption paves } \\
\text { the way to a misleading green } \\
\text { publicity. Before a weak State, the } \\
\text { ecologically correct fallacy control } \\
\text { lies on our collectiveness, mainly due } \\
\text { to information and participation } \\
\text { principles, that enable building } \\
\text { awareness on a truly sustainable } \\
\text { development need }\end{array}$ \\
\hline
\end{tabular}

Legend: B: Search base; P: Proquest; W: Web of Science; C: Capes; S: Scopus

Source: Developed by the authors.

\section{FINAL CONSIDERATIONS}

The bibliometric survey and critical analysis performed enabled identifying interesting aspects concerning the publications on the greenwashing subject, especially among the articles published in journals rated in Qualis in Business Administration, Accounting and Tourism (ACT) field.

The first publication identified dates from 1995, and the term was simply mentioned, and it was found again only in 2003. Discussions about its concept and application were noted from 2007 to 2015. It is evident, thus, the discussion and the subject study recentness within the academia. Due to that, the community that discusses this subject is still small, as such productions involved 110 authors, out of which only four are repeated, having produced two articles each.

The texts produced reached a high excellence level, as one can realize that, out of 42 articles found in the platforms analyzed and published in journals rated in Qualis, 26 were published in journals with rating A1, 5 articles in journals A2, 8 in journals B1 and the 3 remaining ones were published in journals B2, B3 and B4. Out of this journal set, only four were Brazilians.

It is also worth noting the balance existing among the research methods used in the articles, which focus on quantitative and qualitative approaches, and theoretical articles. Such fact implies that different background and bias researchers are concerned with the subject.

However, the precariousness the subject has been approached can be seen as one realizes that most articles analyzed (19) merely mentioned greenwashing, not deepening into the subject, and another six articles develop the thematic superficially (2) or as background (4). Therefore, only 17 out of 42 articles analyzed actually develop the greenwashing subject deeply. 
These 17 articles respond for recentness and relevance even more expressive, with almost all of them published between the years of 2012 and 2015 and in journals with rating A1, A2 or B1. Analyzing more specifically, it was observed among these 17 articles, thirteen articles present the greenwashing in the work general purpose, that can be rated in two main points: articles aimed at surveying or identifying the greenwashing and those aimed at some greenwashing aspects that can influence or suffer influence of the greenwashing practice, including market assessment, social media influence, and the government role, the pros and cons of this practice and the consumer trust impact. Among these, the results suggest, first, an impasse regarding the existence or potentiality of the practice of greenwashing and the non-detection of this in the investigated organizations. Second, some possible actions that would be able to regulate or even curb the practice of greenwashing by organizations such as government and law, social media, and society's information and participation were indicated. The negative consequences of this practice in the consumer market were also highlighted, such as greater skepticism and risk perceived by consumers regarding the green images propagated by the organizations, as well as diminished confidence in them.

In spite of that, there is a consensus in the concern and criticism related to several organization trend to adopt the greenwashing practice to promote themselves, in general or concerning sustainability or corporate social responsibility reports. This tendency is pointed out as a result of the new demands of the market for ecologically correct or sustainable positions that require an adaptation of the organizations to be able to compete in this new competitive context. Thus, it can be said that the theoretical proposition that organizations embark on the practice of greenwashing in the eagerness to take advantage of the benefits of the green image by a relatively simpler, yet irresponsible, path has empirical support.

Thus, it was possible to realize that the greenwashing subject, despite being - apparently increasingly mentioned in the works, is still not widely studied deeply by the academia. Therefore, new studies are suggested concerning the subject, mainly in two strands.

The first strand indicates a concern regarding the identification and / or investigation of the practice of greenwashing, mainly in order to contribute to its detection, with a view to possible actions to combat or inhibit it. The second part, in turn, recommends a deeper understanding of the effects and consequences of this practice, whether in the market as a whole, in society or in the consumer public.

These research gaps highlight the importance of disseminating and deepening greenwashing. It should be emphasized that it is the opinion of the analyzed articles, as well as of these authors, that only by filling the aforementioned gaps, a greater understanding of the practice of greenwashing will be possible, which will not only contribute to this practice de detected more easily, but mainly, that it is possible to combat it and even minimize its negative repercussions. Therefore, it is argued that the urgency regarding the discussion about greenwashing is justified both by its relevance in the theoretical field and by its overwhelming practical implications.

\section{REFERENCES}

Abdala, P. R. Z., Guzzo, R. F., \& Santos, S. A. (2010). Propaganda Verde ou fachada verde? Uma análise do nível de greenwash nos anúncios com apelos ecológicos no Brasil. In Anais do Encontro Internacional sobre Gestão Empresarial e Meio Ambiente - ENGEMA, 12aedição. Faculdade de Economia, Administração e Contabilidade da Universidade de São Paulo.

Ariztia, T., Kleine, D., Brightwell, M. G. S. L., Agloni, N., Afonso, R., \& Bartholo, R. (2014). Ethical consumption in Brazil and Chile: institutional contexts and development trajectories. Journal of Cleaner Production, v. 63, p. 84-92.

Bansal, P., \& Roth, K. (2000). Why companies go green. A model ecological responsiveness. The Academy of Management Journal, v. 43, n. 4, 717-737

Bekessey, S. A., Samson, K., \& Clarkson, R. E. (2007). The failure of non-binding declarations to achieve university sustainability: a need for accountability. International Journal of Sustainability in Higher Education, v. 8, n. 3, p.301-316.

Berrone, P., Fosfuri, A., \& Gelabert, L. (2015). Does Greenwashing Pay Off? Understanding the Relationship Between Environmental Actions and Environmental Legitimacy. Journal of Business Ethics, p. $1-17$. 
Boehmer-Christiansen, S. (1995). Reflections on scientific advice and EC transboundary pollution policy. Science and Public Policy, v.22, n. 3, p.195-203, 1995.

Budinsky, J., \& Bryant, S. (2013). It's not easy being green: the greenwashing of environmental discourses in advertising. Canadian Journal of Communication, v.38, p.207-226.

Carbone, V., \& Moatti, V. (2011). Towards greener supply chains: an institutional perspective. International Journal of Logistics Research and Applications: A Leading Journal of Supply Chain Management, v.14, n. 3, p. 179-197.

Chen, Y., \& Chang, C. (2013). Greenwash and Green Trust: The Mediation Effects of Green Consumer Confusion and Green Perceived Risk. Journal of Business Ethics, v. 114, n. 3, p. 489-500.

Conejero, M. A., \& Fava Neves, M. (2006). Maketing Ambiental e redes internacionais: o caso da Orsa Florestal. Revista Ibero Americana de Estratégia, v.5, n.1, p. 75-85.

Du, X.. (2015). How the Market Values Greenwashing? Evidence from China. Journal of Business Ethics, v. 128, n. 3, p. 547-574.

Garland, J., Huising, \& R., Struben, J. (2013). What if technology worked in harmony with nature? Imagining climate change through Prius advertisements. Organization, v. 20, n. 5, p.679-704.

Ginsberg, J. M., \& Bloom, P.N. (2004). Choosing the right green marketing strategy. MIT Sloan Management Review. v. 48, n.1, p. 79-85.

Guimarães, Antonio F. (2012) Marketing verde e a propaganda ecológica. ComCiência, n. 136.

Guo, R., Tao, L., LI, C. B., \& Wang, T. (2015). A Path Analysis of Greenwashing in a Trust Crisis Among Chinese Energy Companies: The Role of Brand Legitimacy and Brand Loyalty. Journal of Business Ethics.

Hahn, R., \& Lulfs, R. (2014). Legitimizing Negative Aspects in GRI-Oriented Sustainability Reporting: A Qualitative Analysis of Corporate Disclosure Strategies. Journal of Business Ethics, v. 123, n. 3, p. 401-420.

Holme, C. (2010). Corporate social responsibility: a strategic issue or a wasteful distraction? Industrial and Commercial Training, v.42, n. 4, p.179-185.

Huang, R., \& Chen, D. (2015). Does Environmental Information Disclosure Benefit Waste Discharge Reduction? Evidence from China. Journal of Business Ethics, v. 129, n. 3, p. 535-552

Jahdi, K. S., \& Acikdilli, G. (2009). Marketing Communications and Corporate Social Responsibility (CSR): Marriage of Convenience or Shotgun Wedding? Journal of Business Ethics, v. 88, n. 1, p. 103-113.

Kim, E., \& Lyon, T. P. (2011). Strategic environmental disclosure: Evidence from the DOE's voluntary greenhouse gas registry. Journal of Environmental Economics and Management, v. 61, n. 3, p. 311-326.

Kleba, J. (2003). Adesão voluntária e Comportamento Ambiental de Empresas Transnacionais do Setor Químico no Brasil. Ambiente \& Sociedade, v. VI, n. 2, p. 25-45.

LAUFER, W. S. (2003). Social Accountability and Corporate Greenwashing. Journal of Business Ethics, v. 43 , n. 3, p. 253-261.

Lebe, S. S., \& Vrecko, I. (2015). Eco-labels and Schemes: A Requisitely Holistic Proof of Tourism's Social Responsibility? Systems Research and Behavioral Science, v. 32, n. 2, p. 247-255.

Lins, L. S., \& Silva, R. N. S. (2009). Responsabilidade Sócio-Ambiental ou Greenwash: Uma Avaliação com Base nos Relatórios de Sustentabilidade Ambiental. Sociedade, Contabilidade e Gestão, v. 4, n. 1.

Lopes, V. N., \& Pacagnan, M. N. (2014). Marketing verde e práticas socioambientais nas indústrias do Paraná. Revista de Administração, v. 49, n.1.

Lund-Thomsen, P., Lindgreen, A., \& Vanhamme, J. (2016). Industrial Clusters and Corporate Social Responsibility in Developing Countries: What We Know, What We do not Know, and What We Need to Know. Journal of Business Ethics, v. 133, n. 1, p. 9-24.

Lyon, T. P., \& Montgomery, A. W. (2013). Tweetjacked: The Impact of Social Media on Corporate Greenwash. Journal of Business Ethics, v. 118, n. 4, p. 747-757. 
Markham, D., Khare, A., \& Beckman, T. (December, 2014). Greenwashing: a proposal to restrict its spread. Journal of Environmental Assessment Policy and Management, v.16, n.4.

Matejek, S., Gossling, T. (2014). Beyond Legitimacy: A Case Study in BP's “Green Lashing”. Journal of Business Ethics, v. 120, n. 4, p. 571-584.

Motta, S. L. S. (2008). Competitividade baseada no marketing ecológico. Revista de Ciências da Administração, v.10, n.22, p. 128-145.

Motta, S. L. S., \& Oliveira, B. (2007). O marketing ecológico como vantagem competitiva. Revista de Gestão da USP, São Paulo, v. 14, n.2, p. 49-59.

Murrayl, J. M., \& Watson, G. J. (2014). A Critical Assessment of Marine Aquarist Biodiversity Data and Commercial Aquaculture: Identifying Gaps in Culture Initiatives to Inform Local Fisheries Managers. Plos One, v.9, p.9.

Nyilasy, G., Gangadharbatla, H., \& Paladino, A. (2014). Perceived Greenwashing: The Interactive Effects of Green Advertising and Corporate Environmental Performance on Consumer Reactions. Journal of Business Ethics, v. 125, n. 4, p. 693-707.

Ottman, J. A. (2014). Marketing Verde. São Paulo. Makron Books.

Panwar, R., Paul, K., Nybakk, E., Hansen, E., \& Thompson, D. (2014). The Legitimacy of CSR Actions of Publicly Traded Companies Versus Family-Owned Companies. Journal of Business Ethics, v. 125, n. 3, p. 481-496.

Parguel, B., Benôit-moreau, F., \& Larceneux, F. (2011). How Sustainability Ratings Might Deter 'Greenwashing': A Closer Look at Ethical Corporate Communication. Journal of Business Ethics, v. 102, p. $15-28$.

Paulet, E., Parnaudeau, M., \& Relano, F. (2015). Banking with Ethics: Strategic Moves and Structural Changes of the Banking Industry in the Aftermath of the Subprime Mortgage Crisis. Journal of Business Ethics, v. 131, n. 1, p. 199-207.

Ploeg, L., V. D., \& Vanclay, F. (2013). Credible claim or corporate spin? A checklist to evaluate corporate sustainability reports. Journal of Environmental Assessment Policy and Management, v.15, n. 3.

Polonsky, M. J. (1994). An Introduction to Green Marketing. Electronic Green Journal, v. 1, n. 2.

Pope, S., \& Waeraas, A. (2015). CSR-Washing is Rare: A Conceptual Framework, Literature Review, and Critique. Journal of Business Ethics.

Prado, R. A. D. P., Silva, M. A., Junqueira, M. C., \& Almeida, L. N. N. (2011). A influência do marketing verde nos hábitos de consumo dos jovens universitários dos cursos de Administração: estudo em Instituições de Ensino Superior (IES). Revista Brasileira de Marketing, vol. 10, n. 2, p. 128-148.

Prakash, A. (2002). Green marketing, public policy and managerial strategies. Business Strategy and the Environment, v. 11, p. 285-297.

Rahman, I., Park, J., \& Chi, C. G. (2015). Consequences of "greenwashing": Consumers' reactions to hotels' green initiatives. International Journal of Contemporary Hospitality Management, v. 27, n. 6, p. 1054-1081.

Relaño, F. (2011). Maximizing social return in the banking sector. Corporate Governance, v. 11, n. 3, p. 274284.

Rodrigues, A. R., Gonçalves, E. J. V., Costa, A. P., Nora, E.S., \& Rezende, D. C. (2013). Marketing Verde e Consumo Consciente. Segmentando o Mercado de Lavras/MG. Revista Espacios, v. 34, n. 4, p. 13.

Roulet, T. J., \& Toubol, S. (2015). The Intentions with Which the Road is Paved: Attitudes to Liberalism as Determinants of Greenwashing. Journal of Business Ethics, v. 128, n. 2, p. 305-320.

Schneider, J. L., Wilson, A., Rosenbeck W., \& Joseph, M. (2010). Pharmaceutical companies and sustainability: an analysis of corporate reporting. Benchmarking: An International Journal, v. 17, n. 3, p. 421-434. 
Sirieix, L., Delanchy, M., Remaud, H., Zepeda, L. Z., \& Gurviez, P. (2013). Consumers' perceptions of individual and combined sustainable food labels: a UK pilot investigation. International Journal of Consumer Studies, v. 37 n. 2, p. 143-151.

Solomon, J. F., \& Edgley, C. R. P. (2008). The abandoned mandatory OFR: a lost opportunity for SER? Social Responsibility Journal, v.4, n. 3, p. 324-348.

Stephenson, E., Doukas, A., \& Shaw, K. (2012). Greenwashing gas: Might a 'transition fuel' label legitimize carbon-intensive natural gas development? Energy Policy, v. 46, p. 452-459.

Terres, M. S., \& Branchi, L. H. (2012). Going Green: consumo sustentável e as estratégias de marketing verde. Revista Eletrônica do Mestrado em Administração da Universidade Potiguar - RAUnP, v. 5, n. 1, p. $33-44$.

Testa, F., Boiral, O., \& Iraldo, F. (2015). Internalization of Environmental Practices and Institutional Complexity: Can Stakeholders Pressures Encourage Greenwashing? Journal of Business Ethics.

Testa, F., Iraldo, F., Tessitore, S., \& Frey, M. (2011). Strategies and approaches green advertising: an empirical analysis of the Italian context. International Journal of Environment and Sustainable Development, v.10, n. 4.

Thomas, G. O., Walker, I., \& Musselwhite, C. (2014). Grounded Theory analysis of commuters discussing a workplace carbon-reduction target: Autonomy, satisfaction, and willingness to change behaviour in drivers, pedestrians, bicyclists, motorcyclists, and bus users. Transportation Research Part F, v. 26, p. 72-81, 2014.

Turano, L. M., Cherman, A., \& Franca, L. S. (November, 2014). Sustentabilidade em uma grande corporação: uma análise da discrepância entre discurso e prática. Rev. Adm. UFSM, v. 7, Edição Especial, p. 111-128.

Walker, K., \& Wan, F. (2012). The Harm of Symbolic Actions and Green-Washing: Corporate Actions and Communications on Environmental Performance and Their Financial Implications. Journal of Business Ethics, v. 109, n. 2, p. 227-242.

Wu, M., \& Shen, C. (2013). Corporate social responsibility in the banking industry: Motives and financial performance. Journal of Banking \& Finance, v. 37, p. 3529-3547.

Data da submissão: 15/02/2017

Data de aceite: 02/08/2017 